\title{
CHINA'S MILITARY RISE AND ITS IMPACT ON INSTABILITY IN EAST ASIA
}

\author{
Angel Damayanti \\ Angel.Darmayanti@uki.ac.id
}

\begin{abstract}
Abstrack
Meningkatnya anggaran militer China lebih dari satu dekade terakhir ini menyebabkan terjadinya instabilitas di kawasan Asia Timur. Hal ini terutama disebabkan karena Jepang merasa terancam dengan strategi China dan karenanya Jepang melakukan perubahan terhadap kebijakan pertahanannya. Jepang yang memiliki masalah perbatasan dengan China di sekitar Laut Timur, beranggapan bahwa modernisasi persenjataan China, terutama yang dilakukan terhadap armada lautnya, bukan ditujukan utk menciptakan stabilitas keamanan kawasan namun sebaliknya, menimbulkan ancaman bagi Jepang dan negara tetangga lainnya. Sebagai reaksi terhadap kebijakan pertahanan China tersebut, Jepang, di samping tetap menikmati kerjasama pertahanan dengan Amerika Serikat, telah memutuskan untuk merubah postur pertahanannya dan meningkatkan anggaran belanja militernya. Meskipun terlalu dini untuk menyatakan akan terjadi perang antara Jepang dan China, namun dinamika yang terjadi pada keduanya menimbulkan persepsi yang beragam bagi negara-negara di kawasan Asia Timur, namun yang paling mencolok adalah meningkatnya perasaan terancam yang akan mengarah pada security dilemma (dilema keamanan).
\end{abstract}

Kata kunci: Modernisasi pertahanan, Instabilitas, Dilema keamanan

The rise of China, both in military and economic over the last decade, has drawn attention to international politics, especially in East Asia which is the region I want to focus in this paper. Its defense expenditure which increased 11.7 - 20.3 per cent ${ }^{1}$ annually brings instability to the region. Although the government of China has acknowledged that its military expenses are reasonable and at appropriate level for its economic development, it inevitably leads other states in the region to seek greater military capabilities, both quantitatively and qualitatively. In response to this - as well as in relation to North Korea's nuclear program - Japan, for instance, has changed its defense strategy. Instead of Russia being a threat as in the case during the Cold War era, China and North Korea are now considered a threat. This is mentioned in Japan's Defense White Paper lately. Thus, Japan decided both to enhance its self-defense power and strengthen its alliance with United States.

\footnotetext{
1 Based on China's military expenditure from its National Defense White Paper on 1998 2010, accessed from http://www.gov.cn/english/official/2005-08/17/content_24165.htm
} 
Obviously the security dilemma has occurred in this region. China has increased its military expenditure very drastically. This causes other countries in the region, mainly Japan - which continues to have a problem with China in East China Sea management - to feel vulnerable and less secure. This situation forces Japan to put in more efforts to modernize its defense capabilities as a response. Moreover, China-Japan's action-reaction related to arms dynamics makes the region unstable. Therefore, the question addressed in this paper is why weapon acquisition process in any country can become a factor to destabilize a certain region. To answer this question I will examine China's military spending and its impact on East Asia region, with a focus on Japan's response.

Accordingly, I will argue that it is due to threat perception that leads to security dilemma and arms race. China's increase of military spending with the justification of its security and defense creates security dilemma to other states. Even though China has explained its reason and motive through diplomacy, it inevitably creates diverse perceptions towards its neighbors. The security dilemma happens particularly when other states perceive their neighbor's military procurement as a threat. This situation forces other states in the region, mainly Japan, to counter-balance China's strategy by increasing its military expenditure. The tension which is created by this action-reaction will heighten the feeling of insecure for both of them and other countries in the East Asia. This later statement supports Buzan's postulation that when the action-reaction component of the arms dynamic remains strong, the security dilemma is active. ${ }^{2}$ Therefore to explain my assumption, this paper is divided into four main sections - China's military power acquisition, Japan's perception towards China's strategy, the action-reaction model and instability in the region.

\section{China's Military Power Acquisition}

Military power is obviously needed by states for certain goals and it can vary from one state to another. Buzan perceives that military capability is used to act intentionally and physically against an object or an unwilling person either defensively or offensively. ${ }^{3}$ On the other hand, Art tries to broaden the purposes of deployment of military forces by stating that it serves at least four utilities: defense, deterrence, compellence ${ }^{4}$ and swaggering. Although Art explained the differences of these purposes explicitly, in practice, these purposes can be overlapping. It may not be easy to distinguish each of these purposes when they are implemented. To some extent it is difficult to ascertain whether a state's military power is used for defence, offence or both goals - particularly for states which have disputes for

2 Barry Buzan \& Eric Herring, The Arms Dynamic in World Politics, Colorado, Lynne Rienner Publishers, Inc., 1998, p. 209.

${ }^{3}$ Ibid., p. 131.

${ }^{4}$ Robert J. Art use the term "compellence" instead of coercion in his article "To What Ends Military Power?" in International Security, Vol. 4. No. 4, Spring 1980, pp. 3-35, as he was influenced by Thomas c. Schelling in his Arms and Influence, New Haven, Yale University Press, 1966, pp 69-86. 
certain period of time. In addition, it is difficult to determine whether its military force is for deterrence or simply swaggering strategy.

When the Chinese government issued its National Defense White Paper - 2010 on March 2011, they declared the implementation of its peaceful development and pursuit of defense military strategy. The spokesman of China's Ministry of National Defense mentioned that for defensive purpose, the expenditure was mainly used for the personnel, training and maintenance, and equipment. He explained that the increase of China's military budget in the last two years is for improving the People's Liberation Army (PLA)'s living standards of both active and reserve forces. In addition, the budget is also allocated for supporting the diversified military tasks in terms of military operations other than war (MOOTW), and encouraging the Revolution Military Affairs (RMA) in this country. ${ }^{5}$

The above official explanation is aimed at justifying China's rise in military expenditure for three reasons. Firstly, the expenditure is merely an attempt to maintain its weaponries. Secondly, the Chinese government is willing to modernize their armaments to counter non state actors' threats - which they have been doing for more than a decade. Thirdly, the increase of China's military budget is to provide better welfare for its military personnel in accordance with the increase of economic development in this country. However, this defense strategy threatens either its potential adversaries or actual opponents especially those who still have unresolved problems with China. This is not to mention that China's strategy can be applied as an offence strategy. China's defense capabilities in fact have the same ability to force other states either to stop what they are doing now or ask them to do something that it wants.

In addition, some observers remain worried about China's military modernization efforts. Its defense strategy allows Chinese government to build its naval, air and missile forces by procuring nuclear-powered submarines, frigates, amphibious landing craft warships, fighter bombers, and destroyers. These destroyers are also completed with supersonics and anti-ship cruise missiles. These procurements have been started since the year 2000. ${ }^{6}$ In 2010, China bought 15 S300 anti-aircraft missiles from Russia which have a range of more than $150 \mathrm{~km}$ and travel at minimum $2 \mathrm{~km}$ per second. ${ }^{7}$ Moreover, China has just launched its first air-craft carrier recently ${ }^{8}$ and obviously China will continue its military procurement.

${ }^{5}$ White Paper of China's National Defense in 2010, can be accessed from

http://news.xinhuanet.com/english2010/china/2011-03/31/c_13806851.htm

${ }^{6}$ Richard A. Bitzinger, “The China Syndromes: Chinese Military Modernization and the Rearming of Southeast Asia," in Working Paper no. 126, Singapore: S. Rajaratnam School of International Studies, May 2007.

${ }^{7}$ "China Buys Air Defense Systems from Russia," accessed from http:/ / www.reuters.com/article/2010/04/02/us-russia-china-arms-idUSTRE6310WG20100402

${ }^{\text {" }}$ China Launches First Aircraft Carrier on Maiden Sea Trial," accessed from http://www.reuters.com/article/2011/08/10/us-china-military-carrier-idUSTRE77900D20110810 
The Chinese government may justify its action by saying that their military modernization is driven at least for three reasons. Firstly, as written in its White Paper, it is for non-conventional threats' anticipation. Secondly, China government intends to create peace and security in the East Asia region, and eventually to make East Asia region independent from external power. ${ }^{9}$ Nevertheless, in relation to anticipate non-traditional threat, China still has to manage some traditional problems, such as with Taiwan which poses political challenge to its "One China" policy. This is in addition with its problem with Japan in Senkaku/Diaoyu dispute in East China Sea and with some countries in South East Asia regarding South China Sea claim. Furthermore, China has a fragile relationship with United States due to its perception towards US hegemonic behavior and US security alliance with Japan and support given to Taiwan and South Korea. This is not to mention the Chinese government's transparency in publishing its military expenses that is still being questioned by many observers. Therefore, its arms build-up - which is classified as part of arms dynamic by Barry Buzan ${ }^{10}$ - could be perceived as a significant threat by other states, particularly in East Asia region which I give attention to in this paper.

\section{Japan's Perception towards China's Military Transformation}

Power can be used as threats as well as rewards. ${ }^{11}$ And for realist scholars military power remains the most important aspect among other elements of national power. However, in this anarchical system the realist will argue that military power will make you feel more threatened than being rewarded. This perception is heightened when a neighbor state acquires more power than your state. Regarding this, Rousseau argues that the weak position of one's military power increases the perception of threat. This happens because nothing in this selfhelp international system can prevent one state from using force against others to resolve a conflict. ${ }^{12}$

Accordingly, threat perception can be created when a state feels insecure or less secure due to other's arms dynamics. Although Cohen says a threat can be inferred either from a certain signal of intention or the adversary's capability, ${ }^{13}$ the perception itself is worsened when the motives and the reasons behind the other's military build-up are ambiguity. Moreover, it is not easy to figure out a state's military acquisition purpose by examining its motives and reasons stated in the government's documents or declared by its spokesmen.

\footnotetext{
9MG. (Prof) Zhu Chenghu, in the Seminar on "Future East Asian Security - A Chinese Perspective," 23 September 2011, at S. Rajaratnam School of International Studies, Singapore.

${ }^{10}$ Barry Buzan \& Eric Herring, op.cit, pp. 75-82.

${ }^{11}$ David L. Rousseau, "Identity, Power, and Threat Perception A Cross-National Experimental Study" in The Journal of Conflict Resolution, Vol. 51, No. 5, Oct 2007, pp. 744-771.

${ }_{12} \mathrm{Ka}$ Po Ng, Interpreting China's Military Power: Doctrine Makes Readiness, NY, Taylor \& Francis, 2005, pp. 1-14.

${ }^{13}$ Raymond Cohen, Threat Perception in International Crisis, London, The University of Wisconsin Press, 1979, p. 5.
} 
A state can explain its intention and justification to modernize its weapon through defense diplomacy as well as encourage confidence building measure but it can not stop others from having their own perception towards its strategy. When China explains its motive to enhance its military capabilities due to unconventional threats, it causes neighbor states, mainly Japan, to be uncertain. They wonder what kind of unconventional threats would be handled by certain kind of armaments. How effective will this military capability be implemented against non-traditional threats? Who can guarantee that its forces are not going to be applied for other traditional threats? This uncertainty then causes other states to create their own perceptions which can be divergent.

In fact, North Korea's nuclear proliferation and China's military transformation impacted Japan's defense strategy significantly. This is not to mention the Sino-North Korea relationship, and China support to North Korea's nuclear program. ${ }^{14}$ In addition, Japan-China's economic relations are strengthened, but not their political and security relations. ${ }^{15}$ The memory of Japan's invasion to China in World War II and their over territorial claims towards Senkaku/Diaoyu islands are still affecting their relations. Thus, Japan views China's effort to modernize its military power is an attempt that is not only aimed at dealing with non-traditional threats but also traditional threats. It can be used, firstly as a tool to expose its position in global politics. Secondly, it is used to force Taiwan with regards of its independence and eventually to repel Japan from Senkaku/Diaoyu islands, as it is written in Japan's Defense White Paper 2010:

"In its military modernization China appears to give particular priority to the Taiwan issue as an issue of national sovereignty and territorial integrity, and for the time being it will probably aim for the improvement of military capabilities to prevent Taiwan's independence and others, but in recent years, China has begun to work on acquiring capabilities for missions other than the Taiwan issue. The military trends of China draw attention from countries in the region, as the country has been steadily growing as a major political and economic power in the region." 16

Japan has seen China's arms build-up particularly in navy capabilities as a threat since they have the East China Sea dispute to settle. Japan-China negotiation on the oil and gas deposits in this sea has not come to end yet. Therefore, the escalation activities of Chinese naval near the gas and oil field in the Senkaku/Diaoyu islands have led to Japan's concern. Regarding this issue, a retired Lieutenant General and Corps Commander of Japan's Northern Army, who later became a professor at Teikyo University, says, "We do not have any concern

14 Russel Ong, China's Security Interests in the 21 ${ }^{\text {st }}$ Century, NY, Routledge, 2007, pp. 75-86.

${ }^{15}$ Takenori Horimoto, "Changing Security Environment Around Japan: A Mid-Term Perspective" in Changing Security Dynamic in Eastern Asia: Focus on Japan, N.S. Sisodia and G.V.C. Naidu (eds), New Delhi, Institute for Defense Studies and Analyses, 2005, pp. 235-256.

16Japan's Defense White Paper - 2010 accessed from

http://www.mod.go.jp/e/publ/w_paper/pdf/2010/11Part1_Chapter2_Sec3.pdf 
about their land forces, only maritime forces like the navy and missiles. A drastic expansion of that kind of capability could be a threat in the future." 17

Moreover, we can see that the role of media can be very important in this situation, as mentioned by Travis, "knowledge about and perceptions come from the mass media."18 The psychological threats mostly addressed when the media exaggerates a state's military procurement. With regards to the media, China has benefitted from the publicity. It demonstrates not only its might in both economic and military power at the regional and international level, but also its seriousness to deter any potential and actual threat towards its sovereignty and territory. On the other hand, Japan may feel more threatened by this publicity and may react.

\section{Action-reaction Model in East Asia}

Threat perception could lead the threatened state either to continue or transform its military strategy. It will continue to do so if it perceives that the existing strategy is still applicable in response to an adversary's strategy. On the contrary it will change its strategy if it is no longer sufficient to counter-balance the power of its opponent. In the case of Japan-China relationship, Japanese government decided to change its defense strategy. ${ }^{19}$ Japan replaced its Cold War era defense strategy into the so-called "Dynamic Defense Force" which shifted its view about China and permits Japan to have power projection. ${ }^{20}$

Regarding this action-reaction relationships, Intriligator and Brito define "arms race" as an interactive acquisition of weapons by two or more states. ${ }^{21}$ Hollist also emphasizes the Richardson's proposition which mentions that states increase their military capabilities primarily in response to the increasing armaments expenditure of an identifiable opponent. ${ }^{22}$ Glaser also notifies that the state's security environment causes the arms race. Moreover, he postulates that arms races are more likely when states are equally powerful. ${ }^{23}$

17"Japan Moves on from the Cold War," accessed from http:www.bbc.co.uk/news/world-asiapacific-12015563, in 13 September 2011.

18 Travis N. Ridout, "News Media Use and Perceptions of Global Threat," presented in the 101st annual meeting of the American Political Science Association, September 1-4, 2005, Washington, D.C, accessed from http://www.wsu.edu/pols/sage/ridout-grosse-apsa05.pdf

${ }^{19}$ Jennifer M. Lind, "Continuity and Change in Japanese Security Policy, in Changing Security Dynamic in Eastern Asia: Focus on Japan," in Changing Security Dynamic in Eastern Asia: Focus on Japan, N.S. Sisodia and G.V.C. Naidu (eds), New Delhi, Institute for Defense Studies and Analyses, 2005, pp. 315-327.

20Japan's Summary of Mid-Term Defense Program (FY 2011 - 2015) accessed from http://www.mod.go.jp/e/d_act/d_policy/pdf/mid_FY2011-15.pdf

${ }^{21}$ Michael D. Intriligator and Dagobert L. Brito, "Can Arms Races Lead to the Outbreak of War?" in The Journal of Conflict Resolution, Vol. 28, No. 1, Mar. 1984, pp. 63-84.

${ }^{22}$ W. Ladd Hollist, "An Analysis of Arms Processes in the United States and the Soviet Union" in International Studies Quarterly, Vol. 21, No. 3, Sep. 1977, pp. 503-528.

${ }^{23}$ Charles L. Glaser, "When Are Arms Races Dangerous? Rational versus Suboptimal Arming," in International Security, Vol. 28, No. 4, Spring 2004, pp. 44-84. 
In response to China's armed forces modernization and North Korea's nuclear proliferation program which began since late 1950s, Japan has revised its defense strategy over the last ten years. Japanese government arranges a New Defense Program Outlines (NDPO) starting from 2001 which mainly prepared JSDF (Japan Self-Defense Forces) to support the US campaign war on terrorism in Afghanistan and United Nations Peace Keeping Operation. Therefore for the first time, after its security agreement with US in 1951, Japan was approved its own power projection capabilities that made it procured UH-60JA multi role helicopters, Hawk surfaceto-air missiles, landing ship tank for helicopters and destroyer-helicopter ships. ${ }^{24}$ This strategy continued until 2009 as proposed in National Defense Program Guideline 2005-2009, with a stronger cooperation with US and to play a greater role in both regional and global security. Recently, Japan has proposed "Dynamic Defense Force" strategy which permits its Defense Minister to shift the land forces to mobile forces.

Following what has been done by Chinese government, the government of Japan also increases their military spending and modernizes their armaments in the last 2 years. Moreover, Japanese military expenditure on 2010 exceeded British's, France's, Germany's and Russia's military spending and it poses the 3rd rank of world military expenditure, right after United States and China. ${ }^{25}$ Japan currently is acquiring six new submarines, equipped with two more of its warships with Aegis missile-defense capabilities and building three additional ground-based missile defense units - systems. ${ }^{26}$ Not to mention, Japan benefitted from its security agreement with the United States which allows it to develop and deploy it missile defense systems for self-defence purposes, with US technology.

\section{Instability in the Region}

Although Chinese and Japanese governments have shown dramatic power acquisitions both quantitatively and qualitatively, it is too early to evaluate if they are heading for war. The gap of military capability between China and Japan is still too big which causes Japan not to activate war first. In addition, to some observers, their interdependence in economies restrains them from doing regrettable actions by both countries. However, their action-reaction on arms dynamic causes an inevitable security dilemma in the region. Butfoy explains how this security dilemma is caused by the sense of threat especially when there is uncertainty in

\footnotetext{
24“Japan's New Defense Posture Towards Power Projection”, in The International Institute for Strategic Studies Strategic Comments, volume 10, issue 8, October 2004 accessed from

http:/ / www.iiss.org/Easysiteweb/getresource.axd?AssetID=699\&Type=Full.pdf

${ }^{25}$ World Wide Military Expenditures - 2011 accessed from http:/ / www.globalsecurity.org/military/world/spending.htm

26 "Japan Shifts Defense Strategy Towards North Korea and China," accessed from http:/ / www.stripes.com/news/pacific/japan/japan-shifts-defense-strategy-toward-n-korea-china1.129085
} 
others' perception. ${ }^{27}$ About this, Jervis perceives that security dilemma can evoke tensions. ${ }^{28}$

In Sino-Japan relations, the action-reaction military strategies not only promote tensions for both parties, it also creates insecurity for other states in the region. Currently tensions coupled with some unresolved problems with neighboring countries trigger instability in East Asia. This is not to mention the perception of Japan as an invader during the World War II and the assumption of China as a revisionist power in the way it approaches Taiwan. Although China government tries to manage some negotiations and arrange economic cooperation with Taiwan, they still use "carrot and stick" approaches. China seems likely not to leave the use of coercion and intimidation to its "One China" policy, as President $\mathrm{Hu}$ Jintao ratified the "Anti-Seccession Law" in March, 2005.29

In addition, diplomacy that is carried out by Chinese government in accordance with a big number and capability of military equipment tend to cause its neighbor states to perceive that China is going to intimidate them. Hu Jintao confirms that China's peaceful development mechanism - that is aimed to justify its modernization - is mainly used for China-Taiwan reunification. ${ }^{30}$ Essentially, this emphasizes what Al Capone says, "You can get further with a kind word and a gun than you can with just a kind word."31

\section{Conclusion}

The Chinese government's decision to modernize its military capabilities which is supported by its amazing economic growth has its own purpose and logical rationale. In addition, during the implementation of its defense strategy over the last decade, China has been publicizing its peaceful military rise through diplomacy as well as media. However, it is not fully understood by its neighbor states in East Asia region, particularly Japan. Instead of being more confident, Japan feels less secure. Japan then shifts its defense strategy that views China and North Korea as its threat and transforms its military posture such that it becomes the $3^{\text {rd }}$ biggest military expenditure country in the world. It inevitably brings both countries to enter into arms race. This arms race in turn promotes tension between them and their neighbors that causes the East Asia region become unstable.

This instability is also worsened by the assumptions made by other countries in the region for these potential superpowers. These perceptions come up with their history and behavior in relation to resolve some existing problems, mainly

\footnotetext{
${ }^{27}$ A. Butfoy, "Offence-Defence Theory and The Security Dilemma: The Problem with Marginalizing The Context", in Contemporary Security Policy, Vol. 18, No. 3, December 1997, pp. 38-58.

${ }^{28}$ Robert Jervis, Perception and Misperception in International Politics, Princeton, Princeton University Press, 1976, p. 67.

${ }^{29} \mathrm{Wu}-\mathrm{ueh}$ Chang and Chien-min Chao, "Managing Stability in the Taiwan Strait: Non-military Policy towards Taiwan under Hu Jintao," in Journal of Current Chinese Affairs, Vol. 38, No. 3, pp. 99-118.

${ }^{30}$ Eugene Tang and Janet Ong, "China Will Use Peaceful Development to Reunite Taiwan," accessed from http:/ / www.bloomberg.com/apps/news?pid=newsarchive\&sid=aqr3uXRjACaw

31 "The Untouchables" accessed from http://www.imdb.com/title/tt0094226/quotes
} 
China. Thus, it is obviously to mention that China's weapons procurement is destabilizing the East Asia region.

\section{References}

Art, Robert J. “To What Ends Military Power?" International Security, Vol. 4. No. 4, Spring 1980.

Butfoy, A. "Offence-Defence Theory and The Security Dilemma: The Problem with Marginalizing The Context", in Contemporary Security Policy, Vol. 18, No. 3, December 1997.

Buzan, Barry \& Eric Herring. The Arms Dynamic in World Politics, Colorado: Lynne Rienner Publishers, Inc., 1998.

Bitzinger, Richard A. "The China Syndromes: Chinese Military Modernization and the Rearming of Southeast Asia," in Working Paper no. 126, Singapore: S. Rajaratnam School of International Studies, May 2007.

Chang, Wu-ueh \& Chien-min Chao. "Managing Stability in the Taiwan Strait: Nonmilitary Policy towards Taiwan under Hu Jintao," in Journal of Current Chinese Affairs, Vol. 38, No. 3, 2009.

Cohen, Raymond. Threat Perception in International Crisis, London: The University of Wisconsin Press, 1979.

Glaser, Charles L. “When Are Arms Races Dangerous? Rational versus Suboptimal Arming," in International Security, Vol. 28, No. 4, Spring 2004.

Hollist, W. Ladd. "An Analysis of Arms Processes in the United States and the Soviet Union" in International Studies Quarterly, Vol. 21, No. 3, Sep. 1977.

Horimoto, Takenori. "Changing Security Environment Around Japan: A Mid-Term Perspective" in Changing Security Dynamic in Eastern Asia: Focus on Japan, N.S. Sisodia and G.V.C. Naidu (eds), New Delhi: Institute for Defense Studies and Analyses, 2005.

Intriligator, Michael D. and Dagobert L. Brito. "Can Arms Races Lead to the Outbreak of War?" in The Journal of Conflict Resolution, Vol. 28, No. 1, Mar. 1984.

Jervis, Robert. Perception and Misperception in International Politics, Princeton: Princeton University Press, 1976.

Lind, Jennifer M. "Continuity and Change in Japanese Security Policy, in Changing Security Dynamic in Eastern Asia: Focus on Japan," in Changing Security Dynamic in Eastern Asia: Focus on Japan, N.S. Sisodia and G.V.C. Naidu (eds), New Delhi: Institute for Defense Studies and Analyses, 2005.

$\mathrm{Ng}$, Ka Po. Interpreting China's Military Power: Doctrine Makes Readiness, NY: Taylor \& Francis, 2005.

Ong, Russel. China's Security Interests in the 21 ${ }^{\text {st }}$ Century, NY: Routledge, 2007.

Rousseau, David L. "Identity, Power, and Threat Perception A Cross-National Experimental Study" in The Journal of Conflict Resolution, Vol. 51, No. 5, Oct 2007. 
China's National Defense White Paper on 1998 - 2010, accessed from http:// www.gov.cn/english/official/2005-08/17/content_24165.htm

China's National Defense White Paper in 2010, can be accessed from http://news.xinhuanet.com/english2010/china/2011-

03/31/c_13806851.htm

Japan's Defense White Paper - 2010 accessed from http://www.mod.go.jp/e/publ/w_paper/pdf/2010/11Part1_Chapter2_Sec 3.pdf

Japan's Summary of Mid-Term Defense Program (FY 2011 - 2015) accessed from http://www.mod.go.jp/e/d_act/d_policy/pdf/mid_FY2011-15.pdf

"China Buys Air Defense Systems from Russia," accessed from http://www.reuters.com/article/2010/04/02/us-russia-china-armsidUSTRE6310WG20100402

"China Launches First Aircraft Carrier on Maiden Sea Trial," accessed from http://www.reuters.com/article/2011/08/10/us-china-military-carrieridUSTRE77900D20110810

"Japan Moves on from the Cold War," accessed from http:www.bbc.co.uk/news/world-asia-pacific-12015563, in 13 September 2011.

“Japan's New Defense Posture Towards Power Projection”, in The International Institute for Strategic Studies Strategic Comments, volume 10, issue 8, October 2004 accessed from http:/ / www.iiss.org/Easysiteweb/getresource.axd?AssetID=699\&Type=Ful l.pdf

"Japan Shifts Defense Strategy Towards North Korea and China," accessed from http://www.stripes.com/news/pacific/japan/japan-shifts-defensestrategy-toward-n-korea-china-1.129085

Ridout, Travis N. "News Media Use and Perceptions of Global Threat," presented in the 101st annual meeting of the American Political Science Association, September 1-4, 2005, Washington, DC, accessed from http://www.wsu.edu/pols/sage/ridout-grosse-apsa05.pdf

Tang, Eugene \& Janet Ong. "China Will Use Peaceful Development to Reunite Taiwan," http://www.bloomberg.com/apps/news?pid=newsarchive\&sid=aqr 3uXRjACaw

World Wide Military Expenditures - 2011 accessed from http://www.globalsecurity.org/military/world/spending.htm

Chenghu, Zhu, MG (Prof). Seminar on "Future East Asian Security - A Chinese Perspective," 23 September 2011, at S. Rajaratnam School of International Studies, Singapore. 